ANDRZEJ BUKOWSKI*

Uniwersytet Jagielloński

MARCJANNA NÓŻKA**

Uniwersytet Jagielloński

MARTA SMAGACZ-POZIEMSKA***

Uniwersytet Jagielloński

KAROL KURNICKI****

Uniwersytet Jagielloński

DOI: $10.26485 / \mathrm{PS} / 2018 / 67.1 / 7$

\title{
PARKOWANIE I TROSKA. TEORIA PRAKTYKI W BADANIACH NAD OSIEDLAMI WIELKOMIEJSKIMI
}

\section{Streszczenie}

Artykuł podejmuje kwestię narzędzi teoretycznych w studiach nad współczesnymi wielkomiejskimi osiedlami. Wychodzimy od własnych doświadczeń stosowania w badaniach kategorii więzi sąsiedzkich i kapitału społecznego, wskazując na ich ograniczone możliwości opisywania i wyjaśniania procesów strukturyzacji na poziomie lokalnym. Następnie omawiamy potencjał teorii praktyk społecznych w badaniach nad osiedlami oraz prezentujemy sposób zaaplikowania tego ujęcia $\mathrm{w}$ badaniach terenowych prowadzonych przez nas w trzech miastach: Krakowie, Tychach i Lublinie w latach 2015-2017. Rezultaty przyjętej perspektywy pokazujemy na przykładzie dwóch praktyk społecznych, które określamy jako parkingowanie i praktyki troski. Pierwsza wynika przede wszystkim z trudnych lub niemożliwych do pogodzenia

* Dr hab., Zakład Socjologii Sfery Publicznej, Instytut Socjologii.

** Dr hab., Zakład Socjologii Stosowanej i Pracy Socjalnej, Instytut Socjologii.

*** Dr hab., Zakład Socjologii Stosowanej i Pracy Socjalnej, Instytut Socjologii; adres korespondencyjny: e-mail: marta.smagacz-poziemska@uj.edu.pl

**** Dr., Zakład Socjologii Stosowanej i Pracy Socjalnej, Instytut Socjologii; e-mail: kurnicki@, gmail.com 
interesów wykorzystywania przestrzeni osiedlowej. Praktyki troski zakorzenione są w strukturach emocji i przekonań praktykujących. Wykorzystanie w badaniach teorii praktyk doprowadziło nas między innymi do odkrycia, że poprzez parkowanie wytwarzają się trwałe wzory relacji o charakterze organizacyjnym, normatywnym i klasowo-warstwowym, które prowadzą do powstawania wspólnot parkowania w ramach osiedli. Z kolei praktyki troski, choć mniej widoczne, skutecznie wiążą praktykujących ze sobą i z otoczeniem, umożliwiając wymianę zasobów o nieekonomicznej wartości.

Slowa kluczowe: miasto, osiedle mieszkaniowe, sąsiedztwo, parkowanie, parkingowanie, praktyki troski

\section{WSTĘP}

Artykuł ma dwa główne i uzupełniające się cele. Pierwszym jest pokazanie możliwości wykorzystania teorii praktyk społecznych w badaniach miejskich, w tym w opisywaniu i wyjaśnianiu procesów strukturyzowania się społeczności wielkomiejskich osiedli. Celem drugim jest omówienie dwóch przykładowych praktyk społecznych organizujących zbiorowości osiedlowe na podstawie wyników badań empirycznych prowadzonych przez nas w Krakowie, Tychach i Lublinie ${ }^{1}$. Określamy je jako praktyki parkowania (lub parkingowanie) oraz praktyki troski. Pierwsze wynikają przede wszystkim z trudnych lub niemożliwych do pogodzenia interesów wykorzystywania przestrzeni osiedlowej. Drugie zakorzenione są w strukturach emocji i przekonań praktykujących. Wybraliśmy je z obszerniejszego katalogu praktyk zbudowanego w trakcie analizy materiału empirycznego, aby pokazać zróżnicowane, a nawet kontrastowo odmienne mechanizmy praktyk.

W pierwszej części tekstu odwołujemy się do naszych wcześniejszych doświadczeń w badaniach nad społecznościami osiedlowymi. Dzielimy się nimi po to, aby pokazać, które założenia badawcze okazały się nietrafione, stając

1 Badania przeprowadzono w ramach projektu „Różnice i granice w procesie tworzenia wielkomiejskich społeczności sąsiedzkich. Studium społeczno-przestrzenne”, realizowanego ze środków Narodowego Centrum Nauki, nr umowy UMO-2014/15/B/HS6/01949. Zespół badawczy w składzie: Marta Smagacz-Poziemska (kierownik projektu), Andrzej Bukowski, Marcjanna Nóżka, Karol Kurnicki. W trakcie trwania projektu zespół został poszerzony o Krzysztofa Bierwiaczonka oraz Natalię Martini. W artykule wykorzystano materiał z wywiadów prowadzonych przez autorki i autorów artykułu (badania w Krakowie, w Tychach i Lublinie) i przez Krzysztofa Bierwiaczonka (badania w Tychach). 
się jednocześnie inspiracją do poszukiwania nowego spojrzenia teoretycznego. W naszym przypadku było to przejście od badania społeczności osiedlowych przez pryzmat więzi czy kapitału społecznego do badania ich przy użyciu kategorii praktyk społecznych. Omówieniu przyjętego modelu praktyki w ujęciu Theodore Schatzkiego [2002] oraz podstawowych założeń realizowanego projektu poświęcona jest druga część artykułu. Po przedstawieniu metodologii badań empirycznych prezentujemy główne ustalenia dotyczące dwóch wymienionych przykładów praktyk. Opisując i kategoryzując wiązki czynności, które składają się na wymienione praktyki, oraz odtwarzając sposób ich organizacji, a także osadzenia w szerszych wymiarach (czasowych, przestrzennych, materialnych) i kontekstach, proponujemy możliwe ścieżki interpretacyjne i kierunki dalszej analizy.

\section{SPOLECZNOŚCI OSIEDLOWE: UJĘCIE KLASYCZNE}

Wśród nas, autorek i autorów niniejszego tekstu, są osoby, które w przeszłości podejmowały badania nad społecznościami miejskimi z wykorzystaniem koncepcji klasycznych, bazujących na pojęciu więzi i kapitału społecznego. Sąsiedztwa i społeczności lokalne ujmowaliśmy wówczas jako struktury społeczno-przestrzenne spajane więziami, które z jednej strony odnoszą się do podzielanych znaczeń, wartości i poczucia przynależności, z drugiej - do obiektywnie zachodzących kontaktów, wspólnej przestrzeni i infrastruktury oraz zależności między mieszkańcami [Kasarda, Janowitz 1974; Kryczka 1981; Turowski 1979; Starosta 1995]. Zgodnie z tymi ujęciami zakładaliśmy w badaniach, że poziom deklarowanego zaufania czy gotowości do współpracy przekłada się na społeczną zwartość lokalnej wspólnoty, co jest zasobem możliwym do wykorzystania na przykład w działaniach rewitalizacyjnych [Bukowski, Jabłońska, Smagacz-Poziemska 2007a; b]. Już wówczas jednak mieliśmy poważne wątpliwości, czy zastosowana w badaniach kategoria kapitału społecznego ma służyć jako zmienna wyjaśniająca czy też wyjaśniana. Podobnie jak inni badacze nie byliśmy w stanie analitycznie oddzielić „społecznych źródeł” kapitału społecznego od jego „społecznych konsekwencji” [Portes 1998: 20].

Przełom w naszym myśleniu o społecznościach osiedlowych był konsekwencją doświadczeń z badań w ramach Pilotażowego Programu Rehabilitacji Osiedli Mieszkaniowych w 2013 i 2014 roku, realizowanego przez Urząd Miasta Krakowa na dwóch krakowskich osiedlach. Jednym z zadań socjologów - poza wypracowaniem i testowaniem metod partycypacyjnego planowania rewitalizacji osiedli - była diagnoza społeczna osiedli, w tym przede wszystkim poznanie 
opinii mieszkańców na temat warunków życia na osiedlu, oczekiwań i pomysłów na zmiany oraz zbadanie kapitału społecznego sąsiedztwa: relacji sąsiedzkich, gotowości do zaangażowania się mieszkańców w sprawy osiedla i ich faktycznego zaangażowania. Ze względów technicznych i merytorycznych podjęliśmy wówczas decyzję o przeprowadzeniu badań na próbie celowej, a mianowicie na mieszkańcach reprezentujących wszystkie mieszkania wybranych sześciu bloków. Względy techniczne wynikały z braku operatu, czyli listy wszystkich rzeczywistych mieszkańców lub gospodarstw domowych osiedla. Wprawdzie spółdzielnia mieszkaniowa była skłonna przekazać informacje o liczbie mieszkań i właścicieli, ale $\mathrm{w}$ związku ze zgłaszanym podczas spotkań z mieszkańcami powszechnym zjawiskiem wynajmowania mieszkań uznaliśmy, że najprawdopodobniej występują duże różnice pomiędzy danymi oficjalnymi i rzeczywistymi. Przesłanki merytoryczne wynikały ze sposobu ujęcia problemu badawczego: chcieliśmy badać relacje pomiędzy mieszkańcami w ramach sąsiedztwa i blok mieszkalny traktowaliśmy jako jednostkę, w ramach której - z racji styczności przestrzennych - takie relacje mogą być identyfikowane. W każdym z osiedli, kierując się kryterium zróżnicowania ze względu na lokalizację, wielkość bloku i status administracyjny (spółdzielnia - wspólnota), wybrano po trzy bloki. Używając kwestionariusza ankiety, badacze i badaczki przeprowadzili rozmowy z ponad 170 mieszkańcami, starając się porozmawiać z osobą reprezentującą każde mieszkanie. Uzupełniające materiały gromadzono podczas spotkań konsultacyjnych. Szczegółowe rezultaty badań omawia raport Diagnoza kapitału spolecznego, jakości życia i funkcjonalności osiedli Ugorek i Olsza II [2014], tu zaznaczymy jedynie wnioski, istotne z punktu widzenia wyjaśniającej mocy koncepcji więzi sąsiedzkich.

Wyniki badań świadczyły o tym, że mamy do czynienia z osiedlami doświadczającymi zmian w strukturze demograficznej: wzrostu udziału ludzi młodych (do 25. roku życia) oraz starszych (po 65. roku życia), co z jednej strony wiązano z popularnością osiedli na rynku najmu mieszkań dla studentów, z drugiej - naturalnym opuszczaniem domów rodzinnych przez osoby w wieku produkcyjnym. Badani z obu osiedli oceniali je jako dość dobre miejsca do życia: podkreślali ich korzystne zlokalizowanie i skomunikowanie, dużą ilość zieleni. Jednocześnie wskazywano brak infrastruktury pozwalającej na spędzanie czasu wolnego i brak oferty instytucji dla różnych grup wiekowych. Pod względem charakteru relacji sąsiedzkich osiedla wpisywały się w model współczesnych społeczności wielkomiejskich osiedli [Frysztacki 1997], z dominacją relacji powierzchownych, związanych z rytuałami codziennego kontaktu w przestrzeni bloku (np. mówienia sobie „dzień dobry”). Głębsze relacje - operacjonalizowane poprzez 
deklaracje otrzymywanej i oferowanej pomocy, podejmowanych działań na rzecz sąsiadów z bloku czy z osiedla oraz definiowanie się w kategoriach wspólnotowych - okazały się bardzo rzadkie i ograniczone do małych, kilkuosobowych grup sąsiadów, znających się od dłuższego czasu. Aplikacyjny cel badań sprawiał, że zespół badawczy był wyczulony na zgłaszanie przez mieszkańców potrzeby wzmacniania relacji międzysąsiedzkich, ale - i co nas nieco zaskoczyło - słabe więzi sąsiedzkie były sporadycznie postrzegane jako zjawisko negatywne czy problematyczne. Tylko kilku respondentów zwróciło uwagę na negatywne skutki anonimowości i braku integracji mieszkańców, wiążąc je z obniżeniem poczucia bezpieczeństwa czy ogólnie satysfakcji z życia na osiedlu. Większość mieszkańców zaadaptowała się do anonimowości na osiedlu, a nawet ceniła tę jego cechę. Dość szybko uświadomiliśmy sobie, że w zasadzie głównym tematem łączącym mieszkańców i angażującym ich w dyskusjach podczas spotkań było parkowanie, w wywiadach zgłaszane przez blisko 30\% badanych w kategorii „główny problem osiedla" i „oczekiwania odnośnie zmian” (inne konkretne zagadnienia były wskazywane przez mniejszy odsetek badanych, np. ,poprawa bezpieczeństwa” - ok. 13\% badanych, ,stworzenie miejsca spotkan”" - 8\%). Zaskakiwała nas ekscytacja mieszkańców tak chętnie dyskutujących o „problemie parkowania” podczas spotkań poświęconych rewitalizacji osiedla i ich względna obojętność wobec kwestii ,słabnących więzi z sąsiadami”. Wykorzystywane wówczas ramy teoretyczne ,więzi sąsiedzkich” oraz nasze badawcze (ale też normatywne) zorientowanie się na ważkość kapitału społecznego wpłynęły na stwierdzenie, że badane osiedla są przykładem ,społeczności lokalnych w kryzysie”.

W jaki sposób badania z 2014 roku wpłynęły na nasz sposób myślenia o konceptualizowaniu i metodologii badań nad społecznościami wielkomiejskich osiedli? Po pierwsze, poddaliśmy refleksji fakt, że postrzegana przez nas jako „będąca w kryzysie" społeczność ocenia swoje miejsce zamieszkania jako względnie dobre do życia. Po drugie, nasze ustalenia sprowokowały poszukiwania bardziej adekwatnej metody analizy tych okoliczności i ich lepszego rozpoznania, która pozwalałaby wyjść poza ich ogólny opis. Po trzecie, zachęciły nas do spojrzenia na osiedla z perspektywy życia codziennego, czyli całokształtu ludzkiej aktywności realizowanej poprzez zwyczajne, rutynowe czynności, zarówno prywatne, jak i publiczne.

Życie codzienne ma charakter spontaniczny, powtarzalny i często bezrefleksyjny, wręcz automatyczny, „to najbardziej oczywista, obecna w bezpośrednim doświadczeniu najbardziej realna, przemożnie narzucająca się naszej percepcji forma bytu" [por. Sztompka 2008: 214]. Badania prowadzone w nurcie socjologii życia codziennego, inspirowane pracami Georga Simmela [1975], Jane Jacobs 
[2015] czy Michela de Certeau [2008], rozwijają się od kilku dekad, zwykle koncentrując się na konkretnym aspekcie, miejskiej praktyce czy rodzaju przestrzeni, np. korzystaniu z ulicy, jedzeniu „na mieście”, robieniu zakupów [Sundaram 2016; Zukin 2009], praktykach kulturowych i kreowania mikroprzestrzeni poza „oficjalnymi” konstruktami miejskimi [Krajewski 2011] i w czasie codziennego przemieszczania się [O’Dell 2009], znaczeniu zwierząt w miejskich praktykach tworzenia i utrzymywania granic społecznych [Sabloff 2001; Tissot 2011], mobilności i zakotwiczaniu przedmiotów w przestrzeni, na przykład rowerów [Aldred, Jungnickel 2013]. Talia Blokland wprost stawia tezę, że codzienne odtwarzanie czynności i współdzielenie historii tworzy praktyki miejskich osiedli, te zaś tworzą miejską wspólnotę [Blokland 2017: 162].

Możliwości dokonania rewizji naszych ustaleń dostrzegliśmy w teorii praktyk społecznych, tak jak ją ujmują Theodore Schatzki [1996, 2002, 2005], Elisabeth Shove i Mika Pantzar [2005, 2012] czy Andreas Reckwitz [2002]. Pojęcie praktyki społecznej jest tu pojmowane inaczej niż w rozumieniu produkcji przestrzeni Henri Lefebvre'a [2010], koncepcji taktyk i strategii Michela de Certeau [2008] czy habitusu Pierre'a Bourdieu [2005], choć ten ostatni miał duży wkład w rozwój teorii praktyk społecznych. Centralną kategorią analityczną w podejściu, z którego korzystamy, jest praktyka społeczna - różnie definiowana przez reprezentantów tego nurtu, ale zawsze zakładająca dynamiczny, relacyjny i kontekstowy charakter rzeczywistości tworzonej przez ludzi w działaniu. W tej perspektywie dyskutowane przez mieszkańców parkowanie jest nie tylko problemem, ale też czynnością, która w określonym kontekście przestrzennych deficytów obrosła w warstwy regul, norm, rozumień i domyślnych sposobów działania w danej społeczności. Kolejny projekt badawczy - którego rezultaty stanowią podstawę dla niniejszego artykułu - odzwierciedlał zwrot w naszym sposobie badania wielkomiejskich osiedli mieszkaniowych.

\section{NOWE PODEJŚCIE: PERSPEKTYWA PRAKTYK SPOLECZNYCH}

Teoria praktyk społecznych to bogaty i wewnętrznie zróżnicowany nurt teoretyczno-metodologiczny. Rozmaite sposoby rozumienia i aplikacji koncepcji praktyk odnajdujemy u Bourdieu [2007], Giddensa [2003], Shove, Pantzar [2005], Warde'a [2005], Blokland [2017], Strengers [2010], którzy przez jej pryzmat analizowali różne aspekty życia społecznego: od procesów strukturyzacji klasowej po praktyki życia codziennego, równocześnie zakładając, że w każdej praktyce społecznej ujawniają się i aktualizują cechy życia społecznego (strukturalne, instytucjonalne, organizacyjne) [Feldman, Orlikowski 2011: 1241]. Możliwość 
przełamania dualizmu mikro-makro była dla nas szczególnie istotna i pozwoliła między innymi na odkrywanie zróżnicowanych ludzkich aktywności przy równoczesnym osadzeniu ich w szerszym społeczno-przestrzennym kontekście.

RYSUNEK 1. Model koncepcji praktyk społecznych Theodore'a Schatzkiego

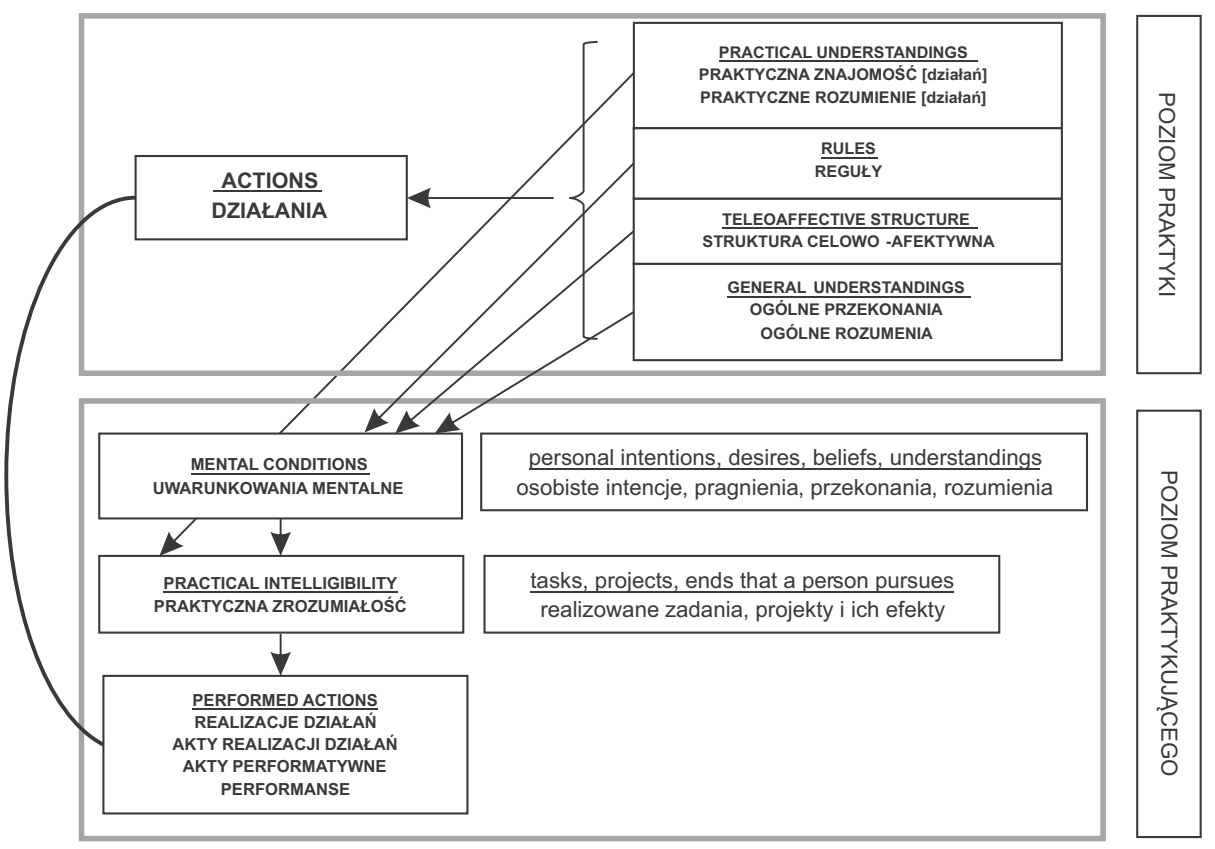

Źródło: schemat opracowany przez Natalię Martini (archiwum projektu).

Przyjmujemy za Schatzkim, że praktyka to otwarte, odtwarzane i dające się przetwarzać, rozciagające się w czasie i przestrzeni wiązki działań podstawowych (czynności cielesnych i językowych - „doings and sayings”) oraz działań złożonych (zadań oraz projektów). Można uznać, że praktyka obejmuje dwa ogólne wymiary: działania i ich organizację. Działania są tu rozumiane performatywnie: mają one nadany przez aktora sens i wykonywane są za pomocą cielesnych czynności, na które składa się to, co ludzie robią i mówią. Co rządzi działaniami i organizuje praktyki? Schatzki uznaje, że jest to, po pierwsze, praktyczne rozumienie, czyli przyjęta definicja operacyjna działania, ucieleśnione know-how. Niewyrażalne za pomocą słów praktyczne rozumienie w przypadku działań prostych oznacza zdolności motoryczne i percepcyjne. Natomiast w przypadku działań złożonych jest ono tożsame ze zdolnościami: wykonywania, rozpoznawania, 
wywoływania oraz reagowania na dane działanie. Praktyczne rozumienie rzadko jednak określa całość tego, co ludzie robią. Kolejnym elementem organizującym działania są reguły danej praktyki oraz struktura celowo-afektywna i uogólnione przekonania [Schatzki 1997; Schatzki 2002: 71 i nast.; Schatzki 2005: 16].

Reguły stanowią jawne lub domyślne formuły nakazujące i/lub zalecające wykonywanie określonych działań przez praktykujących. Określają one, co i jak robić, to znaczy: jakie działania i w jaki sposób powinni lub mogą wykonywać. To swego rodzaju przepisy na wymagane, dopuszczalne lub skuteczne działania, kombinacje działań i ich efekty. Określają, jakie efekty należy lub można osiągać, jakie projekty należy lub można realizować, aby osiagać te efekty, jakie zadania należy lub można wykonywać, aby projekty realizować. Informację na temat wymaganych lub dopuszczalnych efektów zawiera struktura celowo-afektywna, która określa wymagane lub dopuszczalne intencje i pragnienia: co robić, jak robić, po co to robić. O tym, co jest wymagane, dopuszczalne lub skuteczne, decyduje zgoda praktykujących. To przeświadczenia, postawy, wartości, które wyrażają się w tym, co ludzie robią (np. angażują się we wspólną inicjatywę) i w jaki sposób to robią (np. angażują się z poświęceniem).

Omówiony wyżej poziom praktyk społecznych pozostaje w relacji z-zaznaczonym także na modelu (patrz: rysunek 1) - poziomem praktykujących. Ludzie robią zazwyczaj to, co ma dla nich sens w danych okolicznościach, co wpisuje się w ich intencje, pragnienia, przekonania, czyli warunki mentalne. Warunki te są formowane w procesie uczenia się, wykonywania danej praktyki społecznej, za pośrednictwem struktury celowo-afektywnej i reguł określających to, co jest obligatoryjne i akceptowalne w określonej sytuacji.

Praktyki społeczne są ucieleśnione. Ze względu na to, że określone dyspozycje ciała są trudne do wysłowienia, podporządkowane są praktycznemu rozumieniu i milczącej wiedzy. Praktyki konstytuują właściwości ludzkich ciał poprzez wpisywanie w nie pamięci społecznej i wpajanie konkretnych technik posługiwania się ciałem. Po drugie, praktyki wytwarzane i odtwarzane są poprzez to, co ludzie mówią i robią w codziennych sytuacjach. Elementami praktyk są czynności dyskursywne i niedyskursywne, wypowiedzi i działania, wiążące się w wyższego rzędu jednostki, zyskujące sens w odniesieniu do określonej sytuacji lub kontekstu, m.in. symbolicznego, materialnego, czasowego czy przestrzennego. Po trzecie, praktyka społeczna ma wymiar przestrzenny i temporalny - przestrzeń i czas nie są dla niej wyłącznie kontekstem, ale jej istotnym komponentem, wpływającym na przebieg i trwanie praktyki. Po czwarte, każda praktyka rekonstruuje cechy szerszych porządków i struktur społecznych, które z kolei - warunkując przebieg praktyk - aktualizują się i podlegają zmianie poprzez te codzienne 
współdziałania. Po piąte, z praktykami w nierozerwalnym związku pozostają przedmioty, które odgrywają istotną rolę w mediowaniu działania, np. skłaniając ciało do określonych zachowań fizycznych [Schatzki 2005; Jewdokimow 2011; Edensor 2004; Zalewska 2015].

Teorię praktyk społecznych wykorzystaliśmy do analizy mechanizmów różnicowania i wytwarzania granic na poziomie osiedla i w relacji do procesów społecznych zachodzących w innych skalach [Brenner 2004; Jessop, Brenner, Jones 2008$]^{2}$.

\section{METODOLOGIA BADAŃ NAD PROCESAMI STRUKTURYZOWANIA SIĘ ZBIOROWOŚCI OSIEDLOWYCH}

Metodologia wykorzystująca w pełni teorię praktyk społecznych jest w trakcie intensywnego rozwoju. Podejmowane są próby konsolidacji metodologicznej [Jonas, Littig, Wroblewski 2017], ale najczęściej podejście to wykorzystywane jest do analizy konkretnych, wybranych praktyk. Nasze badania stanowiły próbę wypracowania takiej metodologii badań, która pozwoliłaby na analizę różnych praktyk społecznych, osadzonych dodatkowo w złożonej społeczno-przestrzennej rzeczywistości wielkomiejskiego osiedla. Na etapie operacjonalizacji badań utworzyliśmy roboczą listę siedemnastu hipotetycznych praktyk. To między innymi praktyki związane $\mathrm{z}$ relacjami sąsiedzkimi w klatce schodowej (pozdrawianie się, drobne przysługi), z dziećmi (np. zajmowanie się nimi w przestrzeni osiedla), ze zwierzętami (np. wyprowadzanie psów), używaniem przestrzeni bloku, osiedla i otoczenia, z działaniami obywatelskimi czy religijnymi, konsumpcją i mobilnością. Następnie rozpoczęliśmy badania terenowe, wykorzystując przede wszystkim technikę wywiadu pogłębionego. Uzupełniająco realizowane były spacery badawcze i obserwacje terenowe, w trakcie których gromadziliśmy materiał wizualny. Rejestrowano między innymi różne sposoby użytkowania, gospodarowania i znaczenia przestrzeni osiedlowych.

Po transkrypcji i analizie pilotażowych wywiadów oraz skonfrontowaniu materiału z koncepcją Schatzkiego [2002] wypracowaliśmy zestaw procedur, których przestrzeganie warunkowało możliwość kwalifikowania materiału empirycznego do dalszej analizy. Po pierwsze, pytania w wywiadzie koncentrowały się na tym, co robią mieszkańcy danego osiedla (oraz jak nazywają to, co robią) na jego obsza-

2 Przykładowo, są pod wpływem regulacji z poziomu gminy czy państwa oraz ideologii, ale też kontekstów tworzonych przez szczególne sytuacje biograficzne (np. pojawienie się dzieci i ich wychowywanie, wyprowadzenie się dorosłych dzieci z domu, przejście na emeryturę). 
rze i w odniesieniu do niego, w stosunku do jego mieszkańców i niemieszkańców. Po drugie, pytania dotyczyły sposobu realizowania powyższych czynności oraz intencji z tym związanych. Po trzecie, wyeliminowano pytania wprost o emocje, oceny i opinie towarzyszące temu, co ludzie robią oraz o znaczenia przypisywane czynnościom i społeczno-przestrzennym kontekstom. Krótko mówiąc, rdzeń wywiadów stanowiły pytania o to, co ludzie robią, jak to robią i dlaczego to robią. Następnie zakodowano 20 wywiadów, analizując materiał według kodów odpowiadających poszczególnym elementom modelu praktyki (vide rysunek 1). Po krytycznej analizie rezultatów kodowania, kierując się kryterium intensywności, widoczności i kompleksowości, zrekonstruowano listę praktyk. Na obecnym etapie projektu obejmuje ona dziesięć praktyk, m.in. praktyki parkowania, troski, dozorowania, gospodarowania przestrzenią ( $w$ tym grodzenia), wprowadzania się na osiedle, religijne komunikowania się. Nie jest to lista zamknięta, bo dopiero po analizie porównawczej (pomiędzy typami osiedli i pomiędzy miastami) będzie można $\mathrm{z}$ większą pewnością mówić o powszechnych praktykach, ich iteracjach oraz praktykach występujących lokalnie. Wybrane praktyki podlegają dodatkowej, pogłębionej analizie, mającej na celu wypracowanie teoretycznych argumentów związanych z relacją praktyki z szerszymi porządkami, rolą materialności czy podstawą pojawiania się i wykonywania danej praktyki.

Badania były prowadzone zgodnie z metodologią case study, z intencją dalszych studiów porównawczych między przypadkami, zarówno na poziomie osiedli w ramach tego samego miasta, jak i porównań między miastami. W pierwszych fazach badań „przypadek” odnosiliśmy do osiedla rozumianego jako jednostka administracyjna, ale ten wąski sposób rozumienia osiedla został uelastyczniony po części pilotażowej. Administracyjne granice osiedli są tylko jedną z wielu zmiennych wpływających na przestrzenną obecność praktyki społecznej, zatem „osiedle” stało się kategorią pomocniczą w wyznaczaniu terenu badań, ale, mówiąc metaforycznie, to sama praktyka prowadziła nas do kolejnych respondentów czy podsuwała nowe wątki w rozmowach.

W Krakowie do badań pilotażowych wybraliśmy dwa osiedla: modernistyczne z lat 70. XX wieku (KS) oraz osiedle grodzone (KN), gdzie przez około 10 miesięcy testowano techniki badawcze. Następnie kontynuowaliśmy badania z udoskonalonymi narzędziami. Łącznie w Krakowie przeprowadziliśmy 43 wywiady pogłębione (31 KS, $12 \mathrm{KN}$ ). W lutym 2017 roku, czyli po około roku badań terenowych i dokonywanej w tym czasie ewaluacji i korekcie metodyki badań, rozpoczęliśmy badania w Tychach, na dwóch osiedlach: $\mathrm{z}$ lat 50. XX wieku (TS) oraz osiedlu z pierwszej dekady XXI wieku (TN). Niniejszy artykuł bazuje na wynikach analizy 56 wywiadów (TS 31, TN 25). Wiosną 2017 roku 
rozpoczęliśmy badania w Lublinie. Również w tym mieście wywiady pochodzą z dwóch osiedli, starego (LS) oraz nowego (LN). Zbieranie materiałów w tym przypadku zostało niemal zakończone, łączna liczba wywiadów przekracza 50, planowanych jest jeszcze kilka uzupełniających rozmów z osobami, do których wcześniejszy dostęp był utrudniony. W każdym mieście wywiady pogłębione przeprowadzone zostały z mieszkańcami i mieszkankami osiedli, uzupełniały je rozmowy z ekspertami i ekspertkami. We wszystkich przypadkach dobór respondentów był zróżnicowany ze względu na płeć, wiek, status społeczno-ekonomiczny (związany z wykształceniem i sytuacją zawodowa), status własnościowy (właściciel mieszkania - osoba wynajmująca), oraz - na osiedlach starszych - ze względu na długość zamieszkiwania na osiedlu.

\section{PARKINGOWANIE: DOSTĘP I PRAWO DO PARKOWANIA}

Tak jak we wcześniejszych badaniach na osiedlach, także w tych obecnie przez nas realizowanych, kwestie związane z mobilnością okazały się jednym z kluczowych obszarów zainteresowania i aktywności mieszkańców badanych osiedli. Tym razem, przyglądając się im przez pryzmat teorii praktyk, dostrzegliśmy w materiale empirycznym coś więcej niż opis zgłaszanych uciążliwości.

Kwestie powiązane z problematyką parkowania coraz częściej stają się przedmiotem badań i dyskusji prowadzonych między innymi w kontekście zagęszczania się miast. Zwykle pociaga to za sobą refleksję na temat usamochodowienia; prawa do parkowania i parkingowych regulacji, polityk parkingowych [np. Wang, Yuan 2013; Marusek 2012; Wesołowski 2008; Szatan 2012; Wiszniowski 2015; Cass, Faulconbridge 2016]. Zwraca się także uwagę na problem dezorganizacji i zaśmiecania przestrzeni czy niszczenia jej między innymi przez okupowanie samochodami miejsc niewyznaczonych [np. Wang, He 2015]. Mimo że mobilność - a w tym parkowanie - jest analizowana jako ważny element miejskiego życia, jest to jednocześnie temat niedowartościowany w badaniach nad obszarami mieszkaniowymi. Zgromadzony przez nas materiał w sposób szczególny pozwolił na uzupełnienie w tym zakresie wiedzy, uwydatniając między innymi związki praktyk parkowania $\mathrm{z}$ dynamiką relacji sąsiedzkich oraz indywidualnych i zbiorowych interesów powiązanych z użytkowaniem i organizowaniem przestrzeni osiedlowych.

Wypowiedzi badanych o parkowaniu, (nie)dostępności miejsc postojowych i różnych sposobach ,zakotwiczania” [Hannam, Sheller, Urry 2006] samochodu w przestrzeni osiedla tworzą długą listę czynności, rozumień i przekonań. Ich analiza prowadzi do wniosku, że z jednej strony parkowanie dezorganizuje co- 
dzienne życie, bywa źródłem podziałów, prowokuje konflikty, ale z drugiej - dostarcza poczucia komfortu, sprzyja międzyludzkim relacjom, inicjuje sąsiedzkie kontakty. Wszystkie te elementy omawiamy pod wspólnym mianownikiem praktyki parkowania, a w projekcie określamy je jako parkingowanie. Praktyki te osadzone są w różnych kontekstach (np. infrastruktury komunikacyjnej, zagospodarowania przestrzennego) oraz wchodzą w złożone relacje z innymi praktykami społeczno-przestrzennymi, na przykład z omawianym w dalszej części artykułu troszczeniem się o stan przestrzeni osiedlowej (czego przykładem obsadzanie krzewami terenów zielonych, które są rozjeżdżane przez parkujące samochody) czy działaniami powiązanymi z prawami własności (np. odmawianie wydania pozwolenia na parkowanie na terenie osiedla osobie, która wynajmuje mieszkanie).

Na praktyki związane z organizacją przestrzeni parkingowej i regulacją jej dostępności składa się zróżnicowany zbiór działań, które determinowane są przez określone czynniki; cele, intencje i przekonania użytkowników; zbiorowy konsensus co do (braku) słuszności podejmowania takich, a nie innych aktywności, ale także indywidualnych (nie)możliwości ich podjęcia w danych okolicznościach. W życiu codziennym osiedla impuls do organizowania społeczności dają normy: zasady niesformalizowane, niekiedy domyślne lub traktowane jako bezdyskusyjna oczywistość. Ta siła domyślnych zasad ujawniła się we wszystkich osiedlach. Przykładowo, na nowym osiedlu tyskim mieszkańcy parkują „na ukos”, choć znaki nakazują parkowanie równolegle do chodnika - rozmówcy twierdzą, że złamanie tej nieformalnej zasady miałoby poważniejsze konsekwencje niż złamanie oficjalnych przepisów. Na osiedlu w Krakowie mieszkańcy uzgodnili nieoficjalnie z radą dzielnicy, że fragmenty gruntu nie będą obsiewane trawą, żeby zachować ich status ugoru, a przez to utrudnić służbom karanie za parkowanie na tym skrawku ziemi. Ten przykład pokazuje, że normy nieformalne i reguły formalne pozostają wobec siebie w ścisłych relacjach, choć zdarza się, że w przypadku braku regulacji formalnych to normy (nieformalne) przejmuja niemal równoprawną funkcję.

Elementem parkingowania na osiedlu jest parkowanie „na swoim miejscu”, nawet wówczas, gdy formalnie żadne miejsce nie jest przydzielone do konkretnej osoby czy mieszkania. Uznawanie za oczywistość „swojego” lub „czyjegoś” miejsca wyraźnie strukturyzuje zbiorowość, wyznacza kręgi „sąsiadów” (tych, którzy w praktyce uznają ,przynależność miejsca do mnie i mojego samochodu”) i tych, którzy takiego know-how nie posiadają. Taką, często poruszaną w wywiadach, sytuację opisuje respondent z Tychów: 
R: zajmuja [,,moje miejsce”]! jak mnie nie ma. Tylko że ci ludzie, którzy mieszkaja, znaja mnie i tam mnie uszanuje, to mi nie stanie. A taki... taki byle kto, co przyjedzie do kogoś na pót godziny, czy na dwie godziny czy nawet na caly dzień, no to wjeżdża gdzie ma miejsce i no cześćc! [...]

B: a pan wie tė̇ o miejscach zajmowanych przez innych, że pan...

R: to ja im nie wjeżdżam! jedynie gdzieś ustawię się tak, gdzie tam wszyscy stają różnie, nie? I zaglądam, jeżeli się cofnie mi do wieczora, to idę na dót, i se przestawię. A jeżeli nie, no to idę na drugi dzień, jak odjedzie.

Niepisaną zasadą jest zatem powstrzymanie się od zajmowania miejsc, które na podstawie zasiedzenia lub milczącego konsensusu użytkuje któryś z sąsiadów. Niemniej jednak brak formalnych regulacji dotyczących korzystania z miejsc postojowych przy ich równoczesnym deficycie i otwartym dostępie zwykle wzmaga rywalizację. Obowiązującą wówczas regułąjest: kto pierwszy, ten lepszy.

Do innych nieformalnych reguł należą: parkowanie „na styk” (uznaje się, że zajmowanie więcej miejsca niż to jest niezbędne, jest działaniem aspołecznym, złośliwym lub głupim) czy zastawianie samochodu sąsiada własnym pojazdem („bo ja wyjeżdżam rano wcześniej”). Parkingowanie jest złożone z wielu czynności i wymaga dużej wiedzy o innych mieszkańcach posiadających samochody, ich rytmie dnia i nawykach. Jest praktyką, w ramach której może dochodzić do wymiany, a poprzez wymianę budowane są relacje - przykładowo, mieszkańcy pożyczają sobie miejsca parkingowe lub umawiają się na ,przeparkowanie” (ktoś wyjeżdża i informuje przez telefon zaprzyjaźnionego sąsiada, że zwalnia miejsce).

Do repertuaru nieuregulowanych formalnie działań należy także zwracanie uwagi osobom niestosującym się do obowiązujących zasad, słowne napominanie, wkładanie za wycieraczkę samochodu karteczek z informacją o zasadach, z ostrzeżeniem lub inwektywami, wzywanie straży miejskiej.

I tu się pojawiaja problemy, że czasami ktoś nie staną na swoim miejscu, bo przyjechat jakiś gość, a wydawało się, że jest pusty, to ja postawię swój samochód. No i pojawiały się wręcz karteczki, niekiedy z wulgaryzmami, prosze parkować na swoim miejscu, a nie mi tutaj itd.

Kontroli podlega cały repertuar zachowań związanych z ruchem samochodowym na osiedlu i parkowaniem, które w mniej lub bardziej dokuczliwy sposób naruszają indywidualne interesy innych użytkowników przestrzeni osiedlowej. $\mathrm{Z}$ negatywnymi reakcjami spotyka się między innymi zajmowanie miejsca postojowego przez bezużyteczny lub sporadycznie użytkowany samochód. Dezaprobatę wzbudza także nieekonomiczne wykorzystanie przestrzeni wynikające z nieznajomości wewnętrznych zasad regulujących korzystanie z parkingu lub 
niestosowania się do znaków informacyjnych (np. wyrysowanych linii, zakazów parkowania):

...gorzej jak przyjadą obcy, no bo wtenczas nie znaja zwyczajów i czasami tak staja, że na jednym miejscu stoi a mogłyby $w$ tym miejscu trzy samochody stanać.

Deficyt miejsc postojowych powoduje, że popularne jest korzystanie z każdego wolnego miejsca, także znajdującego się na terenach należących formalnie do innej wspólnoty lub spółdzielni, co staje się przyczyną napięć lub otwartych konfliktów. Utrudnienia oraz dyskomfort spowodowane koniecznością parkowania $\mathrm{z}$ dala od swojego bloku, m.in. ze względu na sposoby organizowania przestrzeni parkingowych i regulowania do nich dostępu, niejednokrotnie rodziły niechęć i sprzyjały otwartemu wyrażaniu dezaprobaty:

...blokowanie miejsc, gdzie spokojnie można byłoby zaparkować, nie wiem, komu to przeszkadza [...] ten chodnik można byłoby wykorzystać. [...] coraz więcej jest ulic osiedlowych zablokowanych szlabanami, to jest dla mnie chore.

Kontestacja przyjętych sposobów parkowania i związanych z nim ograniczeń przybiera wiele form. Wyrazem niezadowolenia z restrykcji bądź sposobów regulowania dostępu do przestrzeni osiedlowej bywają pisma - kierowane do administracji osiedla, rad dzielnicy lub urzędu miasta - mające na celu oprotestowanie nieakceptowanych działań, bezpośrednie interwencje w administracji, a także ignorowanie znaków informacyjnych, przesuwanie lub demontowanie donic, dewastowanie ograniczających parkowanie słupków. Mimo postrzeganych deficytów miejsc parkingowych czasami mieszkańcy konsolidowali się także w celu ochrony terenu przed jego dewastacją lub zmianą funkcji, np. w związku z planem budowy parkingu w miejscu dotychczasowej przestrzeni rekreacyjnej. Wyrazem zbiorowego oburzenia i braku zgody na ten stan rzeczy były także protesty, petycje, spontaniczne zgromadzenia i dyskusje prowadzone na klatkach schodowych, przed blokiem, w miejscu planowanej inwestycji.

...gmina nam chciała odebrać działkę [...]. No i ten lasek dalej tam, chcieli to wykarczować wszystko, bo chcieli parkingi porobić, że tu przychodnia, nie ma miejsc na parkingi, że to, że tamto. No i znowu ruszyła lawina, setki ludzi z podpisami nad tym, że powstrzymali gmine...

Przestrzeń parkingowa czasami w całości stawała się przedmiotem kontestacji ze strony zwolenników zagospodarowania osiedla zielenią czy obiektami rekreacyjno-sportowymi.

Działania mieszkańców wydają się balansować między indywidualnymi potrzebami i własną wygodą a wspólnotowymi korzyściami, traktowaniem przestrzeni jako współdzielonej z innymi. Pod presją formalnych regulacji i nie- 
formalnej kontroli społecznej mieszkańcy dostosowują się do zaistniałej sytuacji, czasami podejmując próby negocjowania obowiązujących regulacji.

Parkingowanie absorbuje także osoby, które nie posiadają własnego samochodu, a zainteresowane są rozwiązywaniem problemu niedostatku miejsc postojowych. Zwykle nie są one skłonne ponosić kosztów inwestycji, działań kontrolnych i prewencyjnych, przerzucając je na właścicieli samochodów lub gminę. Zmienia się to $\mathrm{w}$ sytuacji, gdy w posiadaniu miejsca postojowego dostrzegają możliwość realizacji własnych interesów i potrzeb. O ograniczoną przestrzeń wspólną zabiega więc każdy mieszkaniec, bez względu na to, czy posiada samochód, czy nie. W przypadku osób nieposiadających samochodu zabiegi te zwykle wynikają z uznania swojego prawa do fragmentu spółdzielczego parkingu lub chęci pozyskania go dla odwiedzających członków rodziny i znajomych. Zatem to nie tylko organizacja miejsca postojowego dla samego lub samej siebie, ale także dla potencjalnego gościa stanowić może wyzwanie $\mathrm{i}$ istotny element praktyk związanych z parkowaniem.

Analiza praktyk parkowania pokazała istnienie „wspólnot parkingowych”, które powstają na bazie współdzielonych interesów, rozpoznających się i integrujących $\mathrm{w}$ trakcie codziennych praktyk oraz posiadających zdolność do identyfikowania, „oznaczania” i reagowania na rozmaicie postrzeganych obcych parkujących lub łamaczy reguł. Analiza praktyk parkingowania odsłania też różne sposoby konstytuowania się ładu normatywnego, osadzonego zarówno w formalnych regulacjach, jak i nieformalnych uzgodnieniach, negocjowanych w codziennych praktykach.

\section{TROSKA SĄSIEDZKA - TROSKA O SĄSIEDZTWO}

Analizując materiał empiryczny dostrzegliśmy działania, które ze względu na „treść” czynności można było zaklasyfikować do bardzo różnych praktyk: konsumpcji czasu wolnego, uprawiania polityki na poziomie lokalnym czy gospodarowania przestrzenią. Jednak z uwagi na ich podobieństwo pod względem struktury celowo-afektywnej, czyli decydującej roli uczuć i pragnień dla uruchamiania konkretnych czynności, podejmujemy próbę zinterpretowania ich w kategoriach praktyk troski czy praktyk troszczenia się. Pojęcie troski swój obecny status zawdzięcza etyce feministycznej. Zostało wprowadzone jako kategoria moralna związana ze specyficznie kobiecym doświadczeniem troszczenia się o domowników. Jednakże po kilkudziesięciu latach od pojawienia się klasycznej dziś pracy Carol Gilligan [1982], pisanej w duchu sprzeciwu wobec degradowania kobiecej wrażliwości moralnej, sens tego pojęcia uległ daleko idącemu rozszerzeniu, by 
nie rzec uniwersalizacji, choć nadal wszystkie liczące się współczesne koncepcje troski nawiązują do feministycznych korzeni. Dziś etyka troski posiada status klasycznej dziedziny nauk o moralności, a zainteresowanie troską jako uniwersalną kategorią etyczną, taką jak sprawiedliwość czy odpowiedzialność, daleko wykroczyło poza grono etyków i filozofów, stanowiąc obecnie przedmiot ożywionej debaty wśród badaczy zajmujących się polityką społeczną, zarządzaniem publicznym, ale także w środowiskach geografów, socjologów, ekonomistów i politologów [Conradson 2003; Koggel, Orme 2010; Lawson 2007; Łapniewska 2017; Morgan 2010; Sepczyńska 2012; Tronto 2010, Ward, Gahagan 2010; White, Tronto 2004; Waleszczyński 2012]. Nie mamy zamiaru włączać się tutaj w nurt bieżących sporów i kontrowersji wokół pojęcia troski, niemniej zmuszeni jesteśmy przyjąć stanowisko w tych sporach, wprowadzając chociażby robocze rozumienie tej kategorii. Najbliższe jest nam szerokie i inkluzywne ujęcie troski, zaproponowane przez Joan Tronto, która troszczenie się o kogoś (taking care of) pojmuje jako „wszystko to, co robimy dla podtrzymywania, kontynuowania, naprawiania naszego «świata» w taki sposób, że możemy żyć w nim tak dobrze, jak to tylko możliwe" [Fisher \& Tronto 1991: 40; Tronto 1993: 103]. Pojęcie to wychodzi poza zawężające je konotacje, związane z opieką domową i relacjami face to face, i obejmując kontinuum rozmaitych stadiów pośrednich, zmierza w stronę działań i zachowań realizowanych w przestrzeni publicznej dla dobra wspólnego. Ponadto amerykańska badaczka wprost definiuje troskę w kategoriach praktyk społecznych, co wpisuje się w cele naszych analiz - chcemy bowiem wprowadzić pojęcie troski do katalogu praktyk sąsiedzkich oraz sprawdzić, jak praktyki troszczenia się sytuują się w kontekście codziennych relacji i zachowań realizowanych w przestrzeni wielkomiejskiego osiedla.

Praktykowanie troski sąsiedzkiej w oczywisty sposób powiązane jest z bliskością fizyczną, a przez to uwikłane w rozmaite zależności, napięcia, mechanizmy o podłożu społeczno-przestrzennym. Interesuje nas, w jaki sposób praktyki troski realizowane w przestrzeni osiedla strukturyzują relacje sąsiedzkie, a w konsekwencji - osiedlowe zbiorowości. W szczególności chcemy zwrócić uwagę na to, w jaki sposób uwarunkowane szerszymi kontekstami (generacyjnymi, klasowymi, kulturowymi) praktyki troski wchodzą w rozmaite relacje w przestrzeni sąsiedzkiej, uruchamiając z kolei szersze konsekwencje w postaci np. bliższych relacji czy też ich erozji, budowania współpracy i integracji bądź też generowania napięć i konfliktów.

Wstępny rejestr praktyk troski i troszczenia się, realizowanych w bliższym lub nieco dalszym sąsiedztwie, lecz poza przestrzenią ściśle domową, obejmuje gamę działań, które roboczo można podzielić na trzy grupy. Po pierwsze, mamy 
do czynienia z wymianą sąsiedzkiej uwagi i opieki, po drugie, z przykładami zawiązywania wspólnot troszczenia się o innych, a po trzecie, z przejawami troski o sąsiedztwo rozumiane jako wspólna przestrzeń zamieszkania. Relacja wymiany dotyczy wzajemnego, sąsiedzkiego obdarowywania się codzienną uwagą, wyrażania zainteresowania sąsiadami, wyświadczania drobnych przysług, dowiadywania się o zdrowie. Druga grupa działań odnosi się do zawiązywania swoistych kooperatyw troszczenia się o słabszych: dzieci, starszych, chorych, niepełnosprawnych, zwierzęta. Trzeci rodzaj praktykowania troski wiąże się z dbaniem o lokalną przestrzeń, pojmowaną jako dobro wspólne. Występuje w dwóch formach: zinstytucjonalizowanej i obywatelskiej, a dotyczy troszczenia się o wspólne przestrzenie, ich czystość oraz stan utrzymania, o bezpieczeństwo w miejscu zamieszkania, o stan osiedlowej zieleni, o miejsca rekreacji i wypoczynku, wreszcie o estetykę osiedla (pielęgnacja kwiatów, żywopłotów, zgłaszanie aktów wandalizmu, usterek). Zajmiemy się tutaj troską niesformalizowaną, starając się wyjaśnić, w jaki sposób praktyki należące do każdej z tych grup, uwikłane w rozmaite wymiary i konteksty, organizują szersze relacje sąsiedzkie.

Wyróżniona pierwsza grupa praktyk dotyczy troski sąsiedzkiej przejawiającej się w dbałości o podtrzymywanie więzi, odwiedzanie się, pozdrawianie, dopytywanie o sąsiadów:

gdzieś tam jak na korytarzu jestem, czy też sprzątam, to zatrzyma się, pogada, co tam stychać? My tak samo. Czasami się sasiad zapyta o zdrowie męża, tego typu rzeczy.

W trakcie badań ustaliliśmy, że co najmniej na dwóch starych osiedlach wystąpiło zjawisko ,generacyjnego osamotnienia” wśród starszych lokatorów. Jak relacjonuje jeden z mieszkańców krakowskiego osiedla:

...połowę z tych, którzy tutej, połowe, przeciez zostali z tych starych to tylko ja i sasiad$k a$, tutej sasiedzi naprzeciw [...] wszędzie się pozmieniali, wszędzie dochodzili ludzie [...] tak to się tu wymieniało tak rotacyjnie, że człowiek się nie zna, nie utrzymuje [kontaktów]. Natomiast, tak jak mówię, z innymi gdzieś paniami to dzień dobry, dzień dobry, pogada się.

Pierwsi mieszkańcy starszych osiedli (TS), powstających do połowy lat 70 . (KS), po tym, jak ich dorosłe dzieci się wyprowadziły, pozostali sami w swych mieszkaniach, obserwując dynamiczną rotację w składzie mieszkańców własnego i sąsiednich bloków. W przypadku krakowskiego osiedla zjawisko to jest bardziej wyraźne, między innymi dlatego, że niewielkie metrażowo mieszkania skłaniały do wyprowadzki młodsze pokolenia, a wzrost atrakcyjności wynajmu mieszkań w tej lokalizacji spowodował przeznaczenie wielu z nich właśnie na ten cel, zwiększając rotację mieszkańców. W przypadku tyskiego osiedla od niedawna obserwuje się stopniowy napływ przedstawicieli młodego pokolenia klasy 
średniej, skuszonych wygodnymi mieszkaniami oraz samym osiedlem, nieźle skomunikowanym z centrum, funkcjonalnym i spokojnym. W ścisłym związku z wymienionymi tu zjawiskami i istniejącą sytuacją osób starszych pojawiają się dwa warianty sąsiedzkiej troski, opartej na wymianie wzajemnych usług - wewnątrz- i międzygeneracyjnej. O pierwszym rodzaju troszczenia się opowiada jeden ze starszych mieszkańców krakowskiego osiedla, były prezes spółdzielni mieszkaniowej, bardzo zresztą przywiązany do swojego miejsca zamieszkania:

Z sasiadka, która ma różne potrzeby nieraz, awarię czegoś ma czy coś, no to, no to jej trzeba pomóc, mąz nie żyje, trzeba jej pomóc, córka pracuje, tak samo ta wnuczka się zajmuje, to nieraz woda, czy powiedzmy coś tam z gazem, czy z innym. No to mamy umówione sygnaty, to mamy umówione, to już wiem; acha, sygnat, to mówię: Matgosia, no to idę.

W tym przypadku podstawą silnej więzi, wyrażającej się we wzajemnej pomocy, jest wspólna pamięć, związana $\mathrm{z}$ wieloletnim miejscem zamieszkania w sąsiedztwie, wzmocniona podobną sytuacją życiową. Wymiana będąca podstawą wzajemnego troszczenia się o siebie wśród sąsiadów może mieć także wymiar międzygeneracyjny. Przykładu dostarcza relacja młodej mieszkanki osiedla w Tychach:

I na przykład relacje mam takie, że ja wychodzę na dót, sąsiad widzi mnie z balkonu, że ja pilnuję dzieci, to schodzi do mnie porozmawiać. [...] Zostanie mi na przykład, przypilnuje mi dzieci, jako że ja mam dziewięcio i sześciolatka, i boję się ich jeszcze zostawiać samych na podwórku, to zostanie i mówi: „Ola, idź dokończ zupę, ja ci tutaj przypilnuję”.

Odwołując się do teorii praktyk, za podstawę relacji sąsiedzkich w tym przypadku uznalibyśmy komplementarność potrzeb, stanowiących element struktury celowo-afektywnej: z jednej strony chodzi o zaspokojenie poczucia bycia potrzebnym, ale także kontaktów międzyludzkich w przypadku starszych mieszkańców, często mieszkających samotnie, z drugiej - na przykład o wsparcie w opiece nad potomstwem, którego z różnych względów nie są w stanie zrealizować dziadkowie. Głównym źródłem sąsiedzkiej troski w wymiarze generacyjnym okazuje się z jednej strony podobieństwo sytuacji życiowej, charakteryzujące osoby należące do tego samego pokolenia mieszkańców, z drugiej komplementarność potrzeb generacji, znajdujących się w różnym okresie życia i zamieszkujących w bezpośredniej bliskości.

Przejdźmy teraz do drugiej grupy praktyk, w których ujawnia się troska. Przykładem praktyk troszczenia się realizowanych w przestrzeni osiedla, poza sferą domowa, jest opieka nad zwierzętami: Kotami się wzajemnie zajmujemy $z$ sasiadami. Podobnie jest z ptakami, dla których budują karmniki, stawiając je nie tylko na własnych balkonach, lecz także w pobliżu bloku. Z uwagi na to, że 
praktyki troszczenia się realizowane są w przestrzeni wspólnej, to, w jaki sposób się pomaga, niesie bezpośrednie i pośrednie konsekwencje dla wszystkich mieszkających w sąsiedztwie. To, co jednych łączy we wspólnej opiece, u innych budzi sprzeciw. Bywa więc tak, że owe „konsekwencje” troszczenia się o zwierzęta nie spotykają się z akceptacją sąsiadów:

No, ale to znowu ekolodzy podnosza wrzask, żeby w zimie otwierać okienka do piwnic, nikt nie zdaje sobie sprawy... okienka dla kotów, że cala instalacja wodna, CO, w piwnicach, podlega wtedy zamrożeniu i byto zalanie, bo rury popękaty. To nie jest tak, hop siup, otworze okienko, kot sobie wlezie... ale jak rura pęknie, to wie Pani, koszty sa znacznie wyższe, niż to, ze kot sobie wszedt i ogrzat się w tej piwnicy.

Widać tu wyraźnie odmienne sposoby wartościowania opieki, zakorzenione w różnych strukturach celowo-afektywnych. W ramach jednej struktury najważniejszy jest przedmiot naszej troski, w tym wypadku zwierzak, któremu trzeba pomóc, ochronić go przed zimnem. Jego dobrostan pozostaje w centrum zainteresowania, a ewentualne koszty, straty, niedogodności towarzyszące pomocy schodzą na drugi plan. W ramach drugiej bierze się pod uwagę także materialne konsekwencje opieki, a więc m.in. koszty oraz szersze uwarunkowania materialne. Nie jest w tym przypadku bez znaczenia, jakim kosztem ponoszona będzie opieka nad potrzebującymi. Na podobny typ uwarunkowań, które, poprzez praktyki troski, reprodukują z kolei szersze napięcia i podziały, wskazuje inny cytat:

Denerwuje mnie na przykład totalny brud na niektórych balkonach, bo co poniektórzy mieszkańcy dokarmiaja sobie gołębie. A to jest największa zaraza jaka może być, roznosicielstwo chorób.

Zawarta w tym fragmencie wypowiedzi krytyka dokarmiających gołębie, oparta o kryteria porządku, czystości czy generalnie ,gustu”, powiązana jest ze zróżnicowaniem społecznym i - używając terminologii jednego z wczesnych przedstawicieli teorii praktyki Pierre'a Bourdieu [2005] - nosi znamiona klasowej „,dystynkcji”. Zarówno poprzedni przykład, wskazujący na odmienność podejść do kwestii troszczenia się o bezpańskie koty, jak i przykład powyższy uświadamiają nam, że praktyki troski nie są bynajmniej neutralne z punktu widzenia struktury społecznej. Ujawniają bowiem klasowo uwarunkowane emocje zawarte w strukturach celowo-afektywnych różnych grup oraz całościowe sposoby uzasadniania tego komu, dlaczego, jak dalece oraz w jaki sposób powinno się pomagać, co teoria praktyk obejmuje kategorią generalnych rozumień [Welch, Warde 2017]. Odmienność tych cech praktyk, reprodukowana w podejściu do zwierząt, staje się osią osiedlowych podziałów. 
Jeśli chodzi o trzecią grupę wyodrębnionych przez nas zachowań i działań objętych kategorią troski, czyli troszczenie się o przestrzeń osiedlową, większość tego typu praktyk posiada podobną cechę: realizowana jest przez pojedyncze osoby, a nie grupy.

...I tak jest w każdym, no w każdej klatce, że ktoś, z całej klatki właśnie zajmuje się tym ogródkiem. Na przyktad jest taki starszy pan, który, tam klatke obok, ma, no nie za ładny ten ogródek przed, ale właśnie bardzo ładny ma tutaj.

W naszych badaniach znaleźć można wiele przypadków, kiedy ktoś zajmuje się fragmentem zieleni (pielęgnuje mały skwerek, ogródek), jednakże głównie dlatego, że to kawałek ziemi pod jego własnym oknem. Dużo mniej jest przykładów troszczenia się o przestrzeń osiedlową, która nie jest prostym przedłużeniem przestrzeni domowej. Nawet jeśli już się pojawiają, często towarzyszy im kontrprzykład w postaci aktu wandalizmu czy innego typu destrukcji:

...ja już tyle drzew przywiozłem od mojego brata ze wsi, pięknych dębów, a następnego dnia były powyrywane, świadomie.

W naszym materiale znaleźć można bardzo mało współczesnych przykładów świadczących o tym, że troska o dobro wspólne, o przestrzeń osiedlową rozumianąjako całość jest właśnie podzielana przez jakąś większą liczbę mieszkańców. Podzielanie troski o dobro wspólne jest powiązane z tym, czy uczestniczyło się osobiście, czy też nie w jakimś wspólnym akcie „troszczenia się” o to dobro wspólne, jakiejś wspólnej praktyce [Klückmann 2016]. Tropem do takiej właśnie interpretacji są wypowiedzi dotyczące przeszłości osiedlowej, zwłaszcza tzw. czynów społecznych. Jeden ze starszych mieszkańców lubelskiego osiedla wspomina, że jako nastolatek wspólnie z kolegami sadził pierwsze drzewka i siał trawę na osiedlowych zieleńcach. Potem z kolegami pilnowali, czy ktoś nie niszczy efektów ich pracy i przeganiali przyłapanych na gorącym uczynku wandali. W podobnym duchu wypowiada się mieszkaniec krakowskiego osiedla, wspominając wiele wspólnych, osiedlowych inicjatyw realizowanych pod auspicjami spółdzielni mieszkaniowej przez samych mieszkańców. Przekładało się to nie tylko na satysfakcję z efektów wspólnego wysiłku, lecz także na powszechną troskę i zainteresowanie stanem oraz wyglądem osiedla.

Po zmianie systemu nie powstał żaden powszechnie praktykowany zamiennik tzw. czynów społecznych, organizowanych w przestrzeni osiedli wielkomiejskich. Obecnie mamy do czynienia raczej z formalizacją, względnie indywidualizacją działań dla dobra wspólnego. Indywidualizacja aktów troszczenia się o wspólną przestrzeń nie sprzyja upowszechnianiu się dbałości o nią jako dobro wspólne. W wywiadach widać, że dawniej, nim jeszcze procesy rynkowe i migracyjne nie 
były tak zaawansowane, a relacje sąsiedzkie i osiedlowe intensywniej podtrzymywane, troska o dobro wspólne manifestowała się np. we wspólnym sadzeniu drzew, porządkowaniu bezpośredniego otoczenia budynków, sprzątaniu okolicy. Budowało to zarówno poczucie wspólnoty, jak i współodpowiedzialności za przestrzeń osiedlową. Ktoś, kto sam uczestniczył w czynie społecznym, stawał się potem strażnikiem tego, co za sprawą wspólnego wysiłku powstawało. Zbiorową odpowiedzialność za przestrzeń zamieszkania przerzuca się obecnie na instytucje: rady dzielnicowe, spółdzielnie, służby miejskie. Obserwujemy tu głównie podejście „powiernicze”: to przede wszystkim instytucje mają obowiązek troszczyć się o dobro wspólne i jakość przestrzeni.

Podsumowując, odkryliśmy trzy mechanizmy, poprzez które praktyki troski sąsiedzkiej i troski o sąsiedztwo, wchodzące w różnorodne konteksty i uwarunkowania, reprodukują szersze własności strukturalne. Wymiar generacyjny ujawnia relacje wymiany wewnątrz- bądź międzypokoleniowej, stanowiącej podstawę sąsiedzkiej troski, która z kolei staje się ważnym czynnikiem społecznej integracji w warunkach odczuwalnych konsekwencji zmian na rynku mieszkaniowym. Z kolei uwarunkowania klasowe ujawniają się poprzez konsekwencje, jakie praktyki troszczenia się wywołują wówczas, gdy w bezpośrednim sąsiedztwie mieszkają ludzie należący do grup o różnym statusie społecznym i związanej z tym strukturze emocjonalnej oraz poznawczej. Często bywa tak, że konsekwencje działań (praktyk troszczenia się) reprezentantów jednej grupy są negatywnie oceniane przez osoby należące do innej grupy społecznej, co z kolei staje się podstawą reprodukowania różnic klasowych. Wreszcie analiza praktyk zorientowanych na przestrzeń osiedlową, rozumianą jako dobro wspólne wszystkich mieszkańców osiedla, ujawnia zjawisko indywidualizacji starań w tym zakresie przy równoczesnym zaniku niesformalizowanych, grupowych form dbałości o stan przestrzeni sąsiedzkiej, wykraczającej poza otoczenie przydomowe.

\section{ZAKOŃCZENIE}

Celem niniejszego artykułu było zaprezentowanie ujmowania i analizowania społeczności sąsiedzkich w wielkich miastach w perspektywie teorii praktyk społecznych. Impulsem do tego było stwierdzenie słabości eksplanacyjnej istniejących podejść do wielkomiejskich społeczności. W naszych wcześniejszych badaniach pojawily się pytania, na które nie potrafiliśmy znaleźć satysfakcjonującej odpowiedzi, oraz zagadki, których nie dało się rozwiązać. Taką zagadką okazało się to, że tradycyjne pytania o kontakty i powiązania w przestrzeni klatki schodowej, bloku, osiedla nie ujawniały głębokich więzi i relacji - a jeśli takie 
występowały, to w małych, dwu-, trzyosobowych grupach zaprzyjaźnionych sąsiadów. Zaskoczyło nas także, że sami mieszkańcy badanych osiedli traktowali ten fakt raczej z obojętnością. Klasyczne założenie o istnieniu całości społeczno-przestrzennych w postaci społeczności lokalnych (sąsiedzkich) czy innych tego typu wspólnot, przynajmniej w przypadku współczesnych osiedli wielkomiejskich, zostało zweryfikowane negatywnie.

Uznaliśmy, że potrzebne jest inne podejście teoretyczne. Przyjęcie perspektywy praktyk społecznych pozwoliło nam spojrzeć na życie osiedlowe w kontekście codziennych, rutynowych działań i kontaktów oraz spraw, które angażują ludzi. Dopiero ten sposób patrzenia na rzeczywistość umożliwił nam uchwycenie szerszych procesów, zjawisk i mechanizmów. Jedno z podstawowych założeń teorii praktyk społecznych mówi o tym, że w codziennych działaniach reprodukowane są strukturalne kontury życia społecznego [Feldman, Orlikowski 2011: 1241]. Równocześnie cechy szerszych kontekstów i układów społecznych odciskają swe piętno na kształcie codziennych praktyk. Tę wzajemność oddziaływań pomiędzy oboma momentami życia społecznego uznaliśmy za kluczową dla badań nad strukturyzowaniem się społeczności osiedlowych.

Nasze wstępne ustalenia wskazują na bogactwo i intensywność akcji i interakcji realizowanych w różnych skalach, układach, kontekstach i sytuacjach bezpośrednio bądź pośrednio powiązanych z przestrzenią wielkomiejskiego osiedla. Spośród wielu tego typu praktyk wybraliśmy dwie, które dają się wyraźnie scharakteryzować - parkingowanie i troszczenie się. Prześledzenie obu rodzajów praktyk pozwoliło nam wychwycić, w jaki sposób codzienne aktywności i relacje, osadzone w rozmaitych kontekstach i sytuacjach, reprodukują szersze porządki i struktury. Na przykład, obserwacja osiedlowych praktyk parkowania, realizowanych w sytuacji dotkliwego nadmiaru aut, ujawniła sposoby, techniki i strategie normalizowania pełnej napięć i konfliktów przestrzeni codziennych interakcji, związanych z ,zakotwiczaniem” [Hannam, Sheller, Urry 2006] samochodu. W ten sposób odkryliśmy mechanizmy powstawania ładu normatywnego $\mathrm{w}$ jego formalnym i nieformalnym wymiarze, ale także procesy różnicowania, będące konsekwencją podejmowanych regulacji. Z kolei przyjrzenie się praktykom troszczenia się realizowanym wobec sąsiadów, zwierząt czy przestrzeni wspólnej dało wgląd w mechanizmy reprodukowania podziałów klasowych, ujawniających się w konsekwencji tego typu praktyk, ale także w procesy podtrzymywania więzi wewnątrz- oraz międzygeneracyjnych w sytuacji intensywnej rotacji mieszkańców. Analiza praktyk troski w przestrzeni osiedla - ujmująca zarówno relacje człowiek-człowiek, jak i człowiek-nieczłowiek (zwierzęta, rośliny itd.) - pozwala odkryć mechanizmy reprodukujące i modyfikujące struktury 
społeczne w kategoriach współzależności i władzy [Lawson 2007: 6-7]. Daje podstawy i inspiruje zarówno do socjologicznych studiów nad społecznościami miejskimi, z uwzględnieniem perspektywy geograficznej i ekonomicznej, jak i do dyskusji nad fundamentalnymi dziś pytaniami etycznymi, w tym o minimalne granice społecznej odpowiedzialności za innych ludzi i środowisko.

\section{BIBLIOGRAFIA}

Blokland Talja. 2017. Community as urban practice. Cambridge, Malden, MA: Polity Press.

Bourdieu Pierre. 2005. Dystynkcja. Społeczna krytyka władzy sądzenia. tłum. P. Biłos. Warszawa: Wydawnictwo Naukowe Scholar.

Brenner Neil. 2004. New state spaces. Urban governance and the rescaling of statehood. Oxford: Oxford University Press.

Bukowski Andrzej, Barbara Jabłońska, Marta Smagacz-Poziemska. 2007a. Wykluczone sąsiedztwa. Społeczne aspekty rewitalizacji w przestrzeni wielkiego miasta. Kraków: Rabid.

Bukowski Andrzej, Barbara Jabłońska, Marta Smagacz-Poziemska. 2007b. Neighbourhoods in the space of a post-industrial district of a large city. A study of exclusion and marginalisation. $\mathrm{W}$ : Urban rehabilitation in segregated districts of central and eastern European cities, A. Bukowski, K. Fuzer, B. Jabłońska, M. Smagacz-Poziemska (eds.), 168-199. Kraków: Rabid.

Cass Noel, Faulconbridge James. 2016. "Commuting practices: New insights into modal shift from theories of social practice". Transport Policy 45: 1-14.

Certeau Michel de. 2008. Wynaleźć codzienność: sztuki działania. Przeł. K. Thiel-Jańczuk. Kraków: Wydawnictwo Uniwersytetu Jagiellońskiego.

Conradson David. 2003. "Geographies of care: spaces, practices, experiences”. Social \& Cultural Geography 4(4): 451-454.

Diagnoza kapitalu spolecznego, jakości życia i funkcjonalności osiedli Ugorek i Olsza II. 2014. http://rewitalizacja.krakow.pl/aktualnosci/167862,216,komunikat,projekty_naukowe_ugorek_i_olsza_ii.html [dostęp: 15.11.2017].

Doling John, Marja Elsinga. (eds.). 2014. Demographic change and housing wealth. Dordrecht, Heidelberg, New York, London: Springer.

Doling John, Richard Ronald. 2010. "Home ownership and asset-based welfare". Journal of Housing and the Build Environment 25(2): 165-173.

Edensor Tim. 2004. Tożsamość narodowa, kultura popularna i życie codzienne. Kraków: Wydawnictwo Uniwersytetu Jagiellońskiego.

Feldman Martha S., Wanda J. Orlikowski. 2011. "Theorizing practice and practicing theory". Organization Science 22(5): 1240-1253.

Fisher Berenice, Joan C. Tronto. 1991. Toward a Feminist Theory of Care, W: Circles of Care: Work and Identity of Women's Lives, Emily K. Abel i Margaret K. Nelson (eds.), 35-62. State University of New York Press: Albany, NY.

Gilligan Carol. 1982. In a difference voice: Psychological theory and women's development. Cambridge: Harvard University Press.

Hannam Kevin, Mimi Sheller, John Urry. 2006. "Mobilities, immobilities and moorings". Mobilities 1(1): 1-22.

Jacobs Jane. 2015. Śmierć i życie wielkich miast Ameryki. Warszawa: Centrum Architektury. 
Jessop Bob, Neil Brenner, Martin Jones. 2008. "Theorizing sociospatial relations". Environment and planning D: Society and space 26: 389-401.

Jewdokimow Marcin. 2011. Zmiany spotecznych praktyk zamieszkiwania. Warszawa: Wydawnictwo Uniwersytetu Kardynała Stefana Wyszyńskiego.

Jonas Michael, Beate Littig, and Angela Wroblewski. (red.). 2017. Methodological reflections on practice oriented theories. Springer.

Kasarda John D., Morris Janowitz. 1974. "Community attachment in mass society". American Sociological Review (Jun., 1974), 39(3): 328-339.

Klückmann Matthias. 2016. "Practicing community: Outline of a praxeological approach to the feeling of we-ness". Cultural Analysis 15(1): 28-56.

Koggel Christine, Joan Orme. 2010. "Care ethics: New theories and applications". Ethics and Social Welfare 4(2): 109-114.

Kryczka Piotr. 1981. Społeczność osiedla mieszkaniowego $w$ wielkim mieście: ideologie i rzeczywistość. Warszawa: PWN.

Lawson Victoria. 2007. "Geographies of care and responsibility". Annals of the Association of American Geographers 97(1): 1-11.

Lefebvre Henri. 2010. The production of space. Trans. D. Nicholson-Smith. Malden-Oxford Carlton: Blackwell Publishing.

Luckman Thomas. 1989. On meaning in everyday life and in sociology. W: The sociology of everyday life, M. Maffesoli (ed.), 37(1): 17-30. Current Sociology, London: Sage.

Lapniewska Zofia. 2017. „Etyka troski a gospodarka przyszłości”. Praktyka Teoretyczna 24(2): $101-122$.

Maffesoli Michel (ed.). „The sociology of everyday life” 37(1). Current Sociology. London: Sage.

Marody Mirosława. 2014. Jednostka po nowoczesności. Perspektywa socjologiczna. Warszawa: Wydawnictwo Naukowe Scholar.

Marusek Sarah. 2012. Politics of parking: Rights, identity, and property. Routledge.

Morgan Kevin. 2010. "Local and green, global and fair: the ethical foodscape and the politics of care". Environment \& Planning A 42: 1852-1867.

O'Dell Tom. 2009. My soul for a seat. Commuting and the routines of mobility. W: Time, consumption and everyday life: Practice, materiality and culture. E. Shove, F. Trentmann and R. Wilkin (eds.), 85-98. Berg: Oxford, New York.

Portes Alejandro. 1998. "Social capital: Its origins and applications in modern sociology". Annual Review of Sociology 24: 1-24.

Schatzki R. Theodore. 1996. Social practices: A witthensteinian approach to human activity and the social. Cambridge: Cambridge University Press.

Schatzki R. Theodore. 2002. The site of the social. A philosophical account of the constitution of social life and change. The Pennsylvania State University Press.

Schatzki R. Theodore. 2005. Introduction. Practice theory. W: The practice turn in contemporary theory, T.R. Schatzki, K. Knorr Cetina, E. von Savigny (eds.), 10-23. Taylor \& Francis e-Library.

Schatzki R. Theodore. 2017. Sayings, texts and discursive formations. W: The nexus of practices: connections, constellations, practitioners, A. Hui, T. Schatzki, E. Shove (eds.), 126-140. New York: Routledge.

Sepczyńska Dorota. 2012. „Etyka troski jako filozofia polityki”. Etyka 45: 37-61.

Skowrońska Marta. 2014. Jak u siebie. Zamieszkiwanie i komfort. Kraków: Nomos. 
Starosta Pawel. 1995. Poza metropolia. Wiejskie i małomiasteczkowe społeczności lokalne a wzory porządku makrospołecznego. Łódź: Wydawnictwo Uniwersytetu Łódzkiego.

Sztompka Piotr. 2008. Nowe formy życia społecznego a nowy kształt teorii socjologicznej. W: Co nas taczy, co nas dzieli?, J. Mucha, E. Narkiewicz-Niedbalec, M. Zielińska (red.), 213-223. Zielona Góra: Oficyna Wydawnicza Uniwersytetu Zielonogórskiego.

Tronto C. Joan. 1993. Moral boundaries: A political argument for an ethic of care. New York: Routledge.

Tronto C. Joan. 2010. "Creating caring institutions: Politics, plurality, and purpose". Ethics and Social Welfare 4(2): 158-171.

Turner Jonathan. 2002. Face to face: Toward a sociological theory of interpersonal behavior. Stanford: Stanford University Press.

Turowski Jan. 1979. Środowisko mieszkalne w świadomości ludności miejskiej. Wrocław: Ossolineum.

Waleszczyński Andrzej. 2012. „Pojęcie troski we współczesnej etyce”. Studia Philosophiae Christianae 48(2): 143-157.

Walks Alan. 2016. "Homeownership, asset-based welfare and the neighbourhood segregation of wealth". Housing Studies 31(7): 755-784.

Wang Rui, Yuan Quan. 2013. "Parking practices and policies under rapid motorization: The case of China". Transport Policy 30: 109-116.

Wang Donggen, He Shenjing (eds). 2016. Mobility, sociability and well-being of urban living. Springer.

Ward Lizzie, Beatrice Gahagan. 2010. "Crossing the divide between theory and practice: Research and ethic of care". Ethics and Social Welfare 4(2): 210-216.

Welch Daniel, Alan Warde. 2017. How should we understand 'general understandings. W: The nexus of practices: Connections, constellations, practitioners, A. Hui, T. Schatzki, E. Shove (eds.), 183-196. New York: Routledge.

White Julie A., Joan C. Tronto. 2004. "Political practices of care: Needs \& rights". Ratio Juris 17(4): 425-453.

Zalewska Joanna. 2015. Człowiek stary wobec zmiany kulturowej. Perspektywa teorii praktyk społecznych. Warszawa: Wydawnictwo Naukowe Scholar.

Zukin Sharon. 2009. Naked city: The death and life of authentic urban places. Oxford University Press.

Andrzej Bukowski

Marcjanna Nóżka

Marta Smagacz-Poziemska

Karol Kurnicki

\title{
CAR PARKING AND CARE. RESEARCHING URBAN NEIGHBOURHOODS WITH THE THEORY OF SOCIAL PRACTICES
}

\begin{abstract}
The article is based on two different research experiences and describes the theoretical tools that were used in the analysis of large urban neighbourhoods. By reflecting on those experiences, we want to show the limitations of the notions of neighbourhood bonds and social capital in the
\end{abstract}


investigation of structuration processes on the local level. Against this background, we describe the theory of social practices and explain its fitness for the investigation of urban neighbourhoods. This is based on a research project conducted in three Polish cities, Cracow, Tychy and Lublin, between 2015 and 2017.

The article concentrates on car parking and care as two examples of social practices. The prominence of the former results from contradictory interests in the uses of urban space. The latter, in turn, is rooted in the emotional structures and attitudes of practicing actors. The use of the theory of social practices helped us to discover that car parking creates stable patterns of relationships that have an organizational, normative and class-structuring character. These relationships play an important role in the emergence of parkinghoods (i.e. neighbourhoods based on car parking). Practices of care, although less evident, efficiently bind people with each other and with their surroundings, and enable an exchange of non-economic resources.

Keywords: city, housing estate, neighbourhood, car parking, practices of car parking, practices of care 